\title{
NOTES
}

\section{Stomatococcus mucilaginosus gen.nov., sp.nov., ep. rev., a Member of the Family Micrococcaceae}

\author{
T. BERGAN ${ }^{1}$ AND M. KOCUR ${ }^{2}$ \\ Department of Microbiology, Institute of Pharmacy, University of Oslo, Oslo, Norway, ${ }^{1}$ and Czechoslovak \\ Collection of Microorganisms, 66243 Brno, Czechoslovakia ${ }^{2}$
}

\begin{abstract}
The name Stomatococcus mucilaginosus gen.nov., sp.nov., ep.rev., is proposed for a group of organisms previously called "Micrococcus mucilaginosus," a name which is not on the Approved Lists of Bacterial Names. Stomatococcus mucilaginosus consists of gram-positive, encapsulated, nonmotile, non-sporeforming spheres. The distinctive biochemical characters of this organism are as follows: catalase test weakly positive or negative; acid, but not gas, is produced from glucose, trehalose, and glycerol; no acid is produced from mannitol, lactose, or xylose; hydrolyzes gelatin and esculin; produces acetoin; and reduces nitrate to nitrite. This organism is negative in tests for coagulase, deoxyribonuclease, phosphatase, and arginine dihydrolase; it does not grow on nutrient agar supplemented with $5 \% \mathrm{NaCl}$. The guanine-plus-cytosine content of its deoxyribonucleic acid varies between 56 and $60 \mathrm{~mol} \%$. The genus is placed in the family Micrococcaceae since the strains possess most of the characteristics of this family. Four striking differences between $S$. mucilaginosus and species of the genus Micrococcus are found in the following: encapsulation of cells, catalase reaction, ability to grow on nutrient agar supplemented with $5 \% \mathrm{NaCl}$, and guanine-plus-cytosine content of the deoxyribonucleic acid. Strain CCM 2417 (= ATCC $25296=$ NCTC 10663) is the type strain of this new species. $S$. mucilaginosus is the type species of the genus Stomatococcus.
\end{abstract}

Eighteen isolates identified as members of "Micrococcus mucilaginosus" Migula 1900 (11) (not on the Approved Lists of Bacterial Names [15] and not validly published since 1 January 1980 ; hence, without standing in bacterial nomenclature) were reported by Bergan et al. in $1970(3,4)$ and have subsequently been studied by several authors from different points of view. These isolates have been found to differ significantly from currently recognized species of the genus Micrococcus. The guanine-plus-cytosine $(\mathrm{G}+\mathrm{C})$ contents of their deoxyribonucleic acids (DNAs) are 56 to $64.4 \mathrm{~mol} \%$, which is less than the $\mathrm{G}+\mathrm{C}$ contents of the DNAs of the currently accepted Micrococcus species $(4,6,9,12)$, for which a range of 65 to $76 \mathrm{~mol} \%$ has been reported (8). Staphylococcal DNAs have G+C contents of 30 to $40 \mathrm{~mol} \%$ (8). A determination of the fatty acid composition of the cell wall of "M. mucilaginosus" has also shown striking differences between this organism and micrococci and staphylococci (7). Thus, the relative proportion of 14-methyl pentadecanoic acid in " $M$. mucilaginosus" strains was 12 to $22 \%$, in contrast to the value of less than $5 \%$ usually found in micrococci (7). The percentage of $n$ - hexadecanoic acid was also higher than usual for micrococci. There is no serological relationship between " $M$. mucilaginosus" strains and micrococci or staphylococci (P. Oeding, personal communication).

Several phenotypic characters, such as the presence of a thick capsule, poor growth on nutrient agar, a variable catalase reaction, susceptibility to high concentrations of salt, and reactions to several biochemical tests, confirmed that " $M$. mucilaginosus" strains are significantly different from micrococci. BairdParker $(1,2)$ took some of these data into consideration when he placed " $M$. mucilaginosus" among species incertae sedis. This is why " $M$. mucilaginosus" was not included on the Approved Lists of Bacterial Names (15).

The above-mentioned data indicate that the placement of " $M$. mucilaginosus" strains in one of the presently accepted genera of gram-positive cocci cannot be justified. Comparative oligonucleotide cataloging of the $16 \mathrm{~S}$ ribosomal ribonucleic acid of " $M$. mucilaginosus" has supported this view and has indicated that this organism should be regarded as a member of a new genus (10). Therefore, we propose placing 
TABLE 1. Relative fatty acid composition of cells of Stomatococcus mucilaginosus ${ }^{a}$

\begin{tabular}{|c|c|}
\hline Fatty acid & $\begin{array}{l}\text { Relative } \\
\text { amt }(\%)\end{array}$ \\
\hline 12-Methyl tridecanoic. . & $5-12$ \\
\hline n-Tetradecanoic & $2-3$ \\
\hline 13-Methyl tetradecanoic. & $2-3$ \\
\hline 12-Methyl tetradecanoic . . . . . . . . . & $27-43$ \\
\hline$n$-Pentadecanoic . . . . . . . . . . . . . & Trace-12 \\
\hline 14-Methyl pentadecanoic $\ldots . \ldots \ldots \ldots \ldots$ & $12-20$ \\
\hline$n$-Hexadecanoic $\ldots \ldots \ldots \ldots$ & $8-17$ \\
\hline Hexadecanoic . . & 0 \\
\hline hexadecanoic........ & $0-3$ \\
\hline decanoic . . . . . . . . . & $2-12$ \\
\hline ecanoic ... & $0-1$ \\
\hline heptadecanoic ... & $0-1$ \\
\hline$n$-Octadecanoic $\ldots \ldots \ldots \ldots$ & $2-3$ \\
\hline Octadecanoic $\ldots \ldots \ldots$ & $2-4$ \\
\hline ethyl octadec & 0 \\
\hline 16-Methyl octadecanoic & 0 \\
\hline decanoic. & $1-4$ \\
\hline thers. & $1-9$ \\
\hline
\end{tabular}

${ }^{a}$ See reference 7 .

these strains in a new genus, which we name Stomatococcus. We also propose placement of this genus in the family Micrococcaceae. As the strains were initially identified as members of "Micrococcus mucilaginosus," we propose the name Stomatococcus mucilaginosus sp.nov., ep.rev. for these organisms. It should be noted that we are not reviving the name "Micrococcus mucilaginosus," merely the specific epithet. The characteristics of the new genus and species are presented below.

Stomatococcus gen.nov. (Sto.ma.to.coccus.Gr.n. stoma mouth; Gr.n. coccus a grain or berry; M.L.masc.n. Stomatococcus coccus pertaining to the mouth). Cells spherical, 0.9 to 1.3 $\mu \mathrm{m}$ in diameter, arranged mostly in clusters, occasionally in pairs and tetrads. Gram positive. Nonmotile. Encapsulated. Spores are not formed. Facultatively anaerobic. Catalase variable. Optimum growth temperature, 30 to $37^{\circ} \mathrm{C}$. Colonies are usually mucoid, transparent or whitish, and adherent to agar surfaces. Chemoorganotrophic, using a variety of sugars as carbon sources.

Probably a normal inhabitant of the mouth and upper respiratory tract of humans. The $\mathrm{G}+\mathrm{C}$ content of the DNA is 56 to $60.4 \mathrm{~mol} \%$ (as determined by the thermal denaturation and buoyant density methods). The type species is Stomatococcus mucilaginosus sp.nov., ep.rev.

Stomatococcus mucilaginosus sp.nov., ep.rev. (mu.ci.la.gi.no' sus.L.masc.adj. mucilaginosus slimy). Spheres 0.9 to $1.3 \mu \mathrm{m}$ in diameter, mostly variable in size and arranged in clusters, occasionally in pairs and tetrads. Gram positive $(3,4,14)$. Nonmotile. Encapsulated. Spores are
TABLE 2. Phenotypic characteristics of $S$. mucilaginosus strains ${ }^{a}$

\begin{tabular}{|c|c|c|}
\hline Character & $\begin{array}{c}\text { No, of } \\
\text { strains } \\
\text { positive }\end{array}$ & $\begin{array}{l}\text { Reaction of } \\
\text { type strain } \\
\text { CCM } 2417^{b}\end{array}$ \\
\hline Acetoin production & 20 & + \\
\hline Gelatin hydrolysis & 20 & + \\
\hline Nitrate reduction & 20 & + \\
\hline Anaerobic growth & 20 & + \\
\hline Catalase & 14 & + \\
\hline Growth in $5 \% \mathrm{NaCl}$ & 2 & - \\
\hline \multicolumn{3}{|l|}{ Acid production from: } \\
\hline Fructose & 19 & + \\
\hline Glucose & 18 & + \\
\hline Saccharose & 17 & + \\
\hline Glycerol & 17 & + \\
\hline Salicin & 17 & + \\
\hline Trehalose & 15 & + \\
\hline Mannose & 15 & + \\
\hline Maltose & 14 & + \\
\hline Mannitol & 0 & - \\
\hline Raffinose & 0 & - \\
\hline Sorbitol & 0 & - \\
\hline Adonitol & $\mathbf{0}$ & - \\
\hline Coagulase & 0 & - \\
\hline Oxidase reaction & 0 & - \\
\hline Phosphatase & $\mathbf{0}$ & - \\
\hline Tween 80 hydrolysis & 0 & - \\
\hline Urease & 0 & - \\
\hline Starch hydrolysis & 0 & - \\
\hline Citrate (Simmons) & 0 & - \\
\hline $\mathrm{H}_{2} \mathrm{~S}$ & 0 & - \\
\hline Indole production & 0 & - \\
\hline $\begin{array}{l}\text { Phenylalanine } \\
\text { reaction }\end{array}$ & 0 & - \\
\hline
\end{tabular}

${ }^{a}$ See reference 3 .

${ }^{b}$ Symbols: + , positive; - , negative.

not formed. The cell wall contains peptidoglycan of the L-Lys-L-Ser ${ }_{2}$-D-Glu type (13) and does not contain teichoic acids (5). The fatty acid content of the cell wall is shown in Table 1.

Colonies on blood agar are either transparent or whitish, have entire edges, are mucoid with a glistening, smooth, convex surface, and are 1 to $1.5 \mathrm{~mm}$ in diameter. They are adherent to agar surfaces, and this property increases after a few days. Nonhemolytic. Facultatively anaerobic. The catalase reaction is either weakly positive or negative. The benzidine test for porphyrin is positive.

Chemoorganotrophic; metabolism is respiratory and fermentative. Acid, but not gas, is produced from glucose, fructose, galactose, glycerol, mannose, maltose, sucrose, salicin, and trehalose.

Acid is not produced from adonitol, arabinose, cellobiose, dulcitol, inositol, lactose, inulin, mannitol, melibiose, xylose, raffinose, rhamnose, or sorbitol.

Gelatin and esculin are hydrolyzed. Nitrate is 
TABLE 3. Characteristics differentiating Stomatococcus and Micrococcus

\begin{tabular}{|c|c|c|c|c|c|c|c|}
\hline Organism & Cell arrangement & Capsule & Catalase & $\begin{array}{c}\text { Growth on } \\
\text { nutrient agar } \\
\text { containing } 5 \% \\
\mathrm{NaCl}\end{array}$ & $\begin{array}{l}\text { Glycerol } \\
\text { (acid) }\end{array}$ & $\begin{array}{l}\text { Esculin } \\
\text { hydrolysis }\end{array}$ & $\begin{array}{c}\mathrm{G}+\mathrm{C} \text { content } \\
\text { of } \mathrm{DNA} \\
(\mathrm{mol} \%)\end{array}$ \\
\hline $\begin{array}{l}\text { Stomatococcus } \\
\text { mucilaginosus }\end{array}$ & $\begin{array}{l}\text { Clusters, } \\
\text { diplococci }\end{array}$ & $+^{a}$ & $w /-$ & - & + & + & $56-60.4$ \\
\hline $\begin{array}{l}\text { Micrococcus } \\
\text { kristinae }\end{array}$ & Tetrads & - & + & + & + & + & 66.8 \\
\hline Micrococcus spp. & Tetrads, clusters & - & + & + & - & - & $64-75$ \\
\hline
\end{tabular}

${ }^{a}$ Symbols: + , positive reaction; - , negative reaction; $w$, weak reaction.

reduced without gas formation. Acetoin is produced.

The following tests are negative: oxidase, coagulase, deoxyribonuclease, hydrolysis of starch, tyrosine and Tween 80 , phosphatase, urease, arginine dihydrolase, ornithine and lysine decarboxylase, egg yolk reaction, and growth on Simmons citrate agar and on nutrient agar supplemented with $5 \% \mathrm{NaCl}$.

Susceptible to ampicillin, bacitracin, chloramphenicol, erythromycin, fusidic acid, lincomycin, neomycin, novobiocin, oleandomycin, oxytetracycline, and benzylpenicillin. Resistant to lysostaphin and lysozyme $(3,4)$.

Optimum temperature: 30 to $37^{\circ} \mathrm{C}$.

Habitat: frequently isolated from the human mouth and upper respiratory tract. Also found in bronchial secretions and blood cultures $(3,4,6$, 12).

Pathogenicity: may be pathogenic for humans (12). Subcutaneous injection of an undiluted living culture into mice produced local abscesses (3). Large doses may produce fatal disease in mice. Not pathogenic for guinea pigs (3).

Serology: nine strains so far examined possess a similar capsular antigen (Oeding, personal communication).

The $\mathrm{G}+\mathrm{C}$ content of the DNA is 56 to 60.4 mol\% (as determined by the thermal denaturation and buoyant density methods) $(4,6,8,12)$.

The type strain is CCM 2417 (= ATCC 25296 $=$ NCTC 10663).

Description of the type strain. Spheres 0.9 to $1.3 \mu \mathrm{m}$ in diameter, mostly arranged as diplococci, occasionally in pairs and tetrads. Gram positive. Nonmotile. Encapsulated.

Colonies on blood agar are mucoid, 1 to 1.5 $\mathrm{mm}$ in diameter, and dome shaped with entire edges and glistening surfaces; transparent with a tendency toward turning white after several days at room temperature; adherent to agar surfaces; and show no hemolysis.

Chemoorganotrophic. Metabolism is respiratory and fermentative.

Facultatively anaerobic.

The biochemical characteristics of this strain are given in Table 2.
Susceptible to ampicillin, bacitracin, chloramphenicol, erythromycin, fusidic acid, lincomycin, neomycin, novobiocin, oleandomycin, oxytetracycline, and benzylpenicillin. Resistant to lysostaphin and lysozyme $(3,4)$. (4).

The $\mathrm{G}+\mathrm{C}$ content of the DNA is $59.0 \mathrm{~mol} \%$

The cell wall peptidoglycan is of the L-Lys-LSer-L-Ala type (13).

The main characteristics that differentiate $S$. mucilaginosus from members of the genus $\mathrm{Mi}$ crococcus are shown in Table 3. In contrast to Micrococcus species, $S$. mucilaginosus grows poorly on nutrient agar, fails to grow in the presence of $5 \% \mathrm{NaCl}$, and has reactions different from those of micrococci in several key biochemical determinative tests.

\section{REPRINT REQUESTS}

Address reprint requests to: Dr. T. Bergan, Department of Microbiology, Institute of Pharmacy, University of Oslo, P.O. Box 1108, Oslo 3, Blindern, Norway.

\section{LITERATURE CITED}

1. Baird-Parker, A. C. 1974. Family Micrococcaceae, p. 483 In R. E. Buchanan and N. E. Gibbons (ed.), Bergey's manual of determinative bacteriology, 8 th ed. The Williams \& Wilkins Co., Baltimore.

2. Baird-Parker, A. C. 1974. The basis for the present classification of staphylococci and micrococci. Ann. N.Y. Acad. Sci. 236:7-14.

3. Bergan, T., K. Bøvre, and B. Hovig. 1970. Reisolation of Micrococcus mucilaginosus Migula 1900. Acta Pathol. Microbiol. Scand. Sect. B 78:85-97.

4. Bergan, T., K. Bøvre, and B. Hovig. 1970. Priority of Micrococcus mucilaginosus Migula 1900 over Staphylococcus salivarius Andrewes and Gordon 1907, with proposal of a neotype strain. Int. J. Syst. Bacteriol. 20:107113.

5. Bowden, G. H. 1969. The components of the cell walls and extracellular slime of four strains of Staphylococcus salivarius isolated from human dental plaque. Arch. Oral Biol. 14:685-697.

6. Gordon, D. F. 1967. Reisolation of Staphylococcus salivarius from the human oral cavity. J. Bacteriol. 94:12811286.

7. Jantzen, E., T. Bergan, and K. Bøvre. 1974. Gas chromatography of bacterial whole cell methanolysates. VI. Fatty acid composition of strains within Micrococcaceae. Acta Pathol. Microbiol. Scand. Sect. B 82:785-798.

8. Kocur, M., T. Bergan, and N. Mortensen. 1971. DNA base composition of gram-positive cocci. J. Gen. Microbiol. 69:167-183. 
9. Kocur, M., and J. Boháček. 1974. DNA base composition and the classification of non-pigmented micrococci. Microbios 10A:31-38.

10. Ludwig, W., K. H. Schleifer, G. E. Fox, E. Seewaldt, and E. Stackebrandt. 1981. A. phylogenetic analysis of staphylococci, Peptococcus saccharolyticus and Micrococcus mucilaginosus. J. Gen. Microbiol, 125:357-366.

11. Migula, W. 1900. System der Bakterien. Gustav Fischer, Jena.

12. Rubin, S. J., R. W. Lyons, and A. J. Murcia. 1978. Endocarditis associated with cardiac catherization due to a gram-positive coccus designated Micrococcus mucilaginosus incertae sedis. J. Clin. Microbiol. 7:546-549.

13. Schleifer, K. H., and O. Kandler. 1972. Peptidoglycan types of bacterial cell walls and their taxonomic implication. Bacteriol. Rev. 36:407-477.

14. Silva, M. T., J. J. Polónia, and M. Kocur. 1977. The fine structure of Micrococcus mucilaginosus. J. Submicrosc. Cytol. 9:53-66.

15. Skerman, V. B. D., V. McGowan, and P. H. A. Sneath (ed.). 1980. Approved lists of bacterial names. Int. J. Syst. Bacteriol. 30:225-420. 